\title{
RELATIONS OF LATE PALEOZOIC AND EARLY MESOZOIC FORMATIONS OF SOUTHWESTERN MONTANA AND ADJACENT PARTS OF WYOMING.
}

\author{
By D. Dale Condit.
}

SUMMARY OF CONCLUSIONS.

The object of this paper is twofold-to present evidence found in southwestern Montana concerning the great Jurassic base-leveling and its bearing on the solution of certain stratigraphic problems involving late Paleozoic, Triassic, and Jurassic formations, and to set forth the relations of those formations to beds in western Wyoming. The conclusions briefly summarized are as follows:

Prior to the encroachment of the sea from the northwest in late Jurassic time prolonged erosion and base-leveling occurred over much of the Rocky Mountain region. From the Idaho State line near Yellowstone National Park northward to the vicinity of Helena the erosion surface thus produced truncates beds of Triassic and Carboniferous age, through a stratigraphic range of about 1,000 feet.

The Quadrant quartzite at the type locality in the northwestern part of Yellowstone Park is approximately equivalent to the Amsden and Tensleep formations in Wyoming. The Park City (Pennsylvanian and Permian), Dinwoody (Lower Triassic), and Chugwater (largely Triassic) of the Wyoming section are in part represented by the Teton formation of Yellowstone Park. The quartzitic cherty basal beds of the Teton, containing the phosphate rock, are equivalent to the Phosphoria formation of Idaho, which corresponds to the upper part of the Park City formation. In western Montana north of latitude $45^{\circ} 30^{\prime}$ the overlying Triassic shaly limestone and red shale were removed by the Jurassic erosion and the Ellis formation (Upper Jurassic) rests on the pertly eroded Phosphoria formation.

FIELD WORK.

The information set forth in this paper was obtained by the writer during the seasons of 1913, 1915, and 1916. The first two years were spent in detailed mapping of the Permian phosphate beds along the northeast slope of the Wind River Mountains and throughout the Owl Creek Mountains of Wyoming. A reconnaissance trip was also made on both the east and west slopes of the Big Horn Mountains. In 1916 a reconnaissance examination occupying about three months was made in Montana from Helena south to Yellowstone Park and west to longitude $112^{\circ}$, and later in the same season a visit was made to exposures in the vicinity of Cody, Wyo. Nearly all the outcrops in Wyoming represented on the accompanying map (Pl. IX) except those near the Idaho State line were visited, and also practically all those in the Montana area.

\section{FORMATIONS IN SOUTHWESTERN MONTANA DISCUSSED IN THIS PAPER.}

The Madison limestone, of Mississippian age, which ranges in thickness from 200 to 2,500 feet in different parts of Montana, Idaho, and Wyoming, forms an unmistakable unit throughout the region and a convenient datum in the study of the less constant higher beds. Its slightly uneven surface is in places capped by conglomerate made up of pebbles of the Madison limestone in a sandy matrix. No generalized section of beds above the Madison that is representative of all of southwestern Montana can be made, and therefore each formation will be described briefly in turn and illustrated by stratigraphic sections measured at a number of localities.

\section{QUADRANT QUARTZITE.}

The term Quadrant was introduced by Peale $^{1}$ to designate a formation consisting of 150 feet of cherty limestones in the upper part and 200 feet of red limestones below, overlying the Madison limestone in the vicinity

1 Peale, A. C., U. S. Geol. Survey Bull. 110, pp. 39-43, pls. 1, 4, 1893. 
of Three Forks, Mont. The names for the Paleozoic formations in the Three Forks area were stated by Peale ${ }^{1}$ to have been determined "after consultation with the members of Mr. Arnold Hague's division." The strata to which the name Quadrant was applied were therefore doubtless correlated with the strata, mostly quartzitic sandstone, found on Quadrant Mountain, in the northwestern part of Yellowstone Park, for which Arnold Hague and W. H. Weed, who surveyed the park between the years 1883 and 1893, had selected the name Quadrant quartzite. The publication of the Yellowstone Park folio, with four geologic maps, was delayed until 1896. In 1894, however, the name Quadrant quartzite was again used, by Weed, ${ }^{2}$ for the rocks overlying the Madison limestone and underlying the Ellis formation in the Livingston quadrangle, Mont., which doubtless were regarded as equivalent to the typical Quadrant quartzite of the Yellowstone Park. Since 1896 the name has been extensively used for strata in many parts of western Montana supposed to be equivalent to those at the type locality.

Peale did not give any description of the formation at the type locality, and the first published section of the rocks of Quadrant Mountain is that measured by Weed ${ }^{3}$ and quoted on page 117 of this report. It will be noted that the overlying cherty quartzitic beds described as the Phosphoria (Permian) in this paper are included by Weed in the Teton formation. Although the Teton beds of the Yellowstone Park region are also present in the south third of the Three Forks quadrangle, they were mapped as a part of the Ellis (Jurassic) in the Three Forks folio, except that the lower cherty quartzitic portion (Phosphoria) was considered a part of the underlying Quadrant. The reference of the lower part of the Teton to the Quadrant has been followed in all the geologic folios published for areas in western Montana, including the Philipsburg. ${ }^{4}$ Pardee, ${ }^{5}$ however, in a recent report on the Philipsburg region,

\footnotetext{
1 Idem, p. 14.

2 Weed, W. H., U. S. Geol. Survey Geol. Atlas, Livingston folio (No. 1), 1894.

3 U. S. Geol. Survey Mon. 32, pt. 2, p. 34, 1899.

${ }^{4}$ U. S. Geol. Survey Geol. Atlas, Philipsburg folio (No. 196), 1915.

5 Pardee, J. T.,The Garrison and Philipsburg phosphate fields, Mont.:

U. S. Geol. Survey Bull. 640, pp. 206-211, 1917.
}

defines the limits of the Quadrant(?) and Phosphoria formations as applied in that area.

There has been considerable uncertainty concerning the age of the Quadrant quartzite. Peale's studies in the Three Forks quadrangle yielded fossils of Mississippian and Pennsylvanian age. Collections of fossils made years ago by Weed and others northeast of the Three Forks area were found to contain Mississippian forms, and more recent collections northwest of the Three Forks area, within and near the Philipsburg quadrangle, have yielded Pennsylvanian forms. Field work in 1916 showed that the typical Quadrant in the Yellowstone Park, as described by Weed in Monograph 32, included representatives of both the upper Mississippian and the Pennsylvanian.

The Quadrant generally consists of three parts. The basal member is chiefly sandy red shale, slightly calcareous, containing few recognizable marine fossils. This red-shale member is only a few feet thick along the Idaho State line but thickens northward to about 150 feet near Bozeman. Over the red shale is more or less limestone and carbonaceous shale, absent locally but present in widely separated localities and containing abundant fossils, which are believed by G. H. Girty probably to denote early Pennsylvanian age. At the west boundary of Yellowstone Park this limestone is less than 50 feet thick and sparingly fossiliferous, but it thickens westward to 250 feet in the Snowcrest Range, where it is rich in fossils. At Lombard, about 75 miles northeast of the Snowcrest Range, it is nearly as prominent and equally fossiliferous, but at intervening points it is generally thin and contains poorly preserved fossils. The limestone member is overlain by 100 to 400 feet of quartzitic sandstone interbedded with a less amount of sandy dolomitic limestone and thin layers of smooth-textured argillaceous limestone, more or less cherty and containing traces of poorly preserved fossils.

The thickness of the Quadrant is in most places a little more than 300 feet, but from the Gravelly Mountains west to the Snowcrest Mountains the thickness increases from about 500 to nearly 1,000 feet. The formation also thickens northeastward from Lombard, a point on Missouri River about 35 miles northwest of Bozeman. 


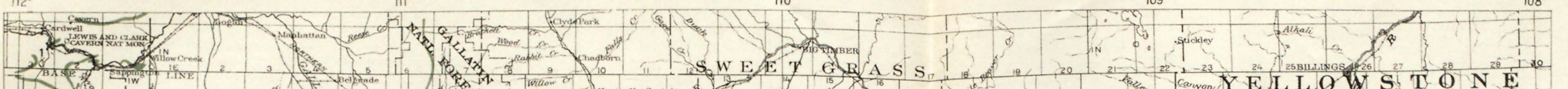

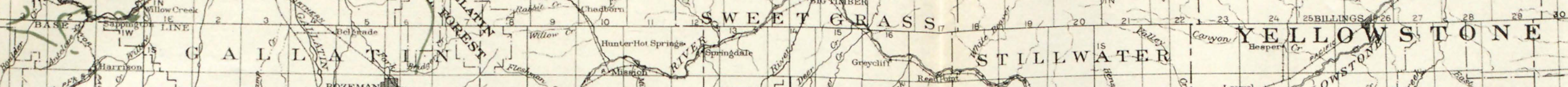

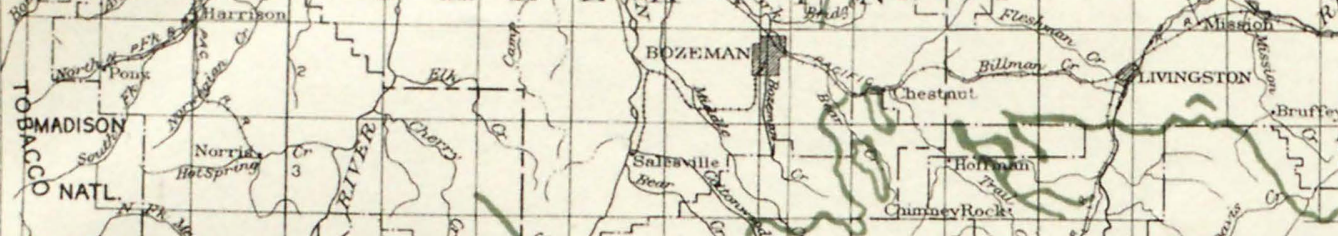
FOREST

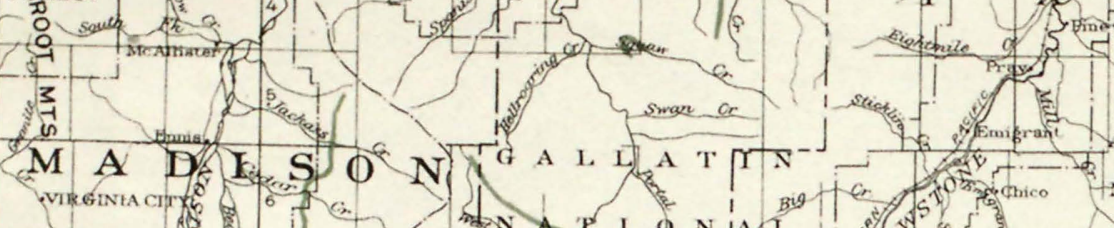

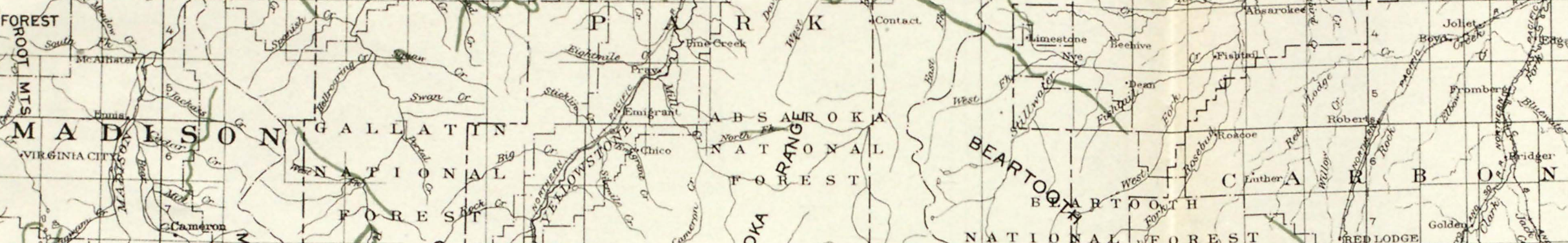

\section{CENTE ENA}

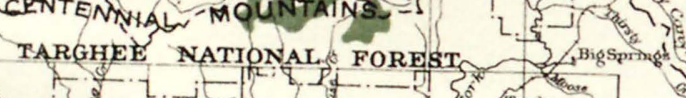

E o 2. t t

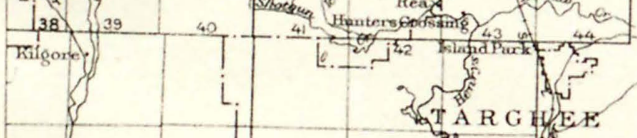

F $\mathrm{R} M \mathrm{M}$

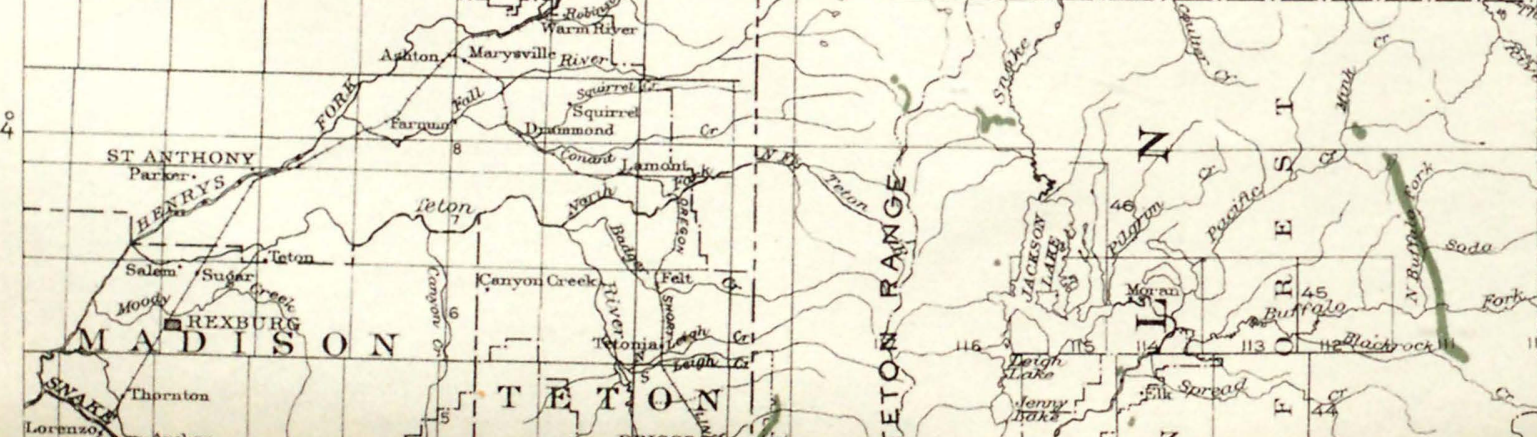

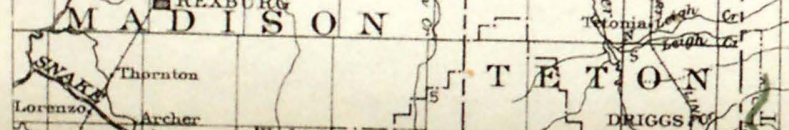
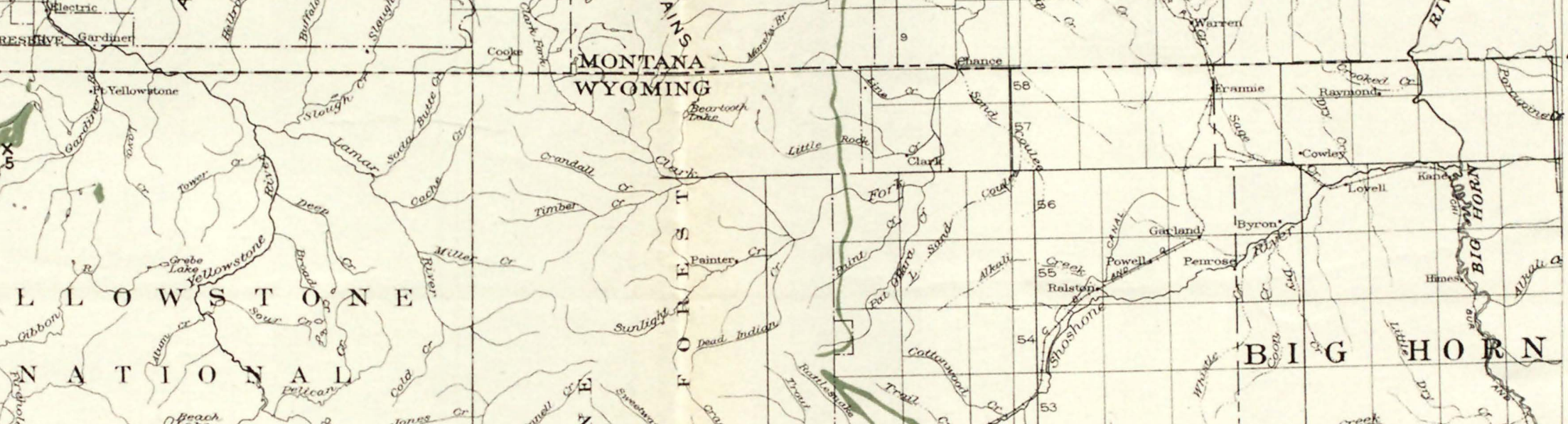


\section{PHOSPHORIA FORMATION.}

The Quadrant proper is overlain by 100 to 250 feet of dark-gray cherty quartzite, layers and ropy masses of nodular chert and shale, with one or more beds of phosphate rock. The sequence is regarded as equivalent to part of the Park City formation of Utah and Wyoming, but more nearly equivalent to the Phosphoria formation of Idaho, as was recognized in 1913 by Richards ${ }^{1}$ and later by Stone and Bonine, ${ }^{2}$ in whose report the name was first published for those beds in Montana. Peale ${ }^{3}$ in mapping the geology of the Three Forks quadrangle, included the Phosphoria beds as a part of the Quadrant, and he has been followed by Calkins ${ }^{4}$ in mapping the Philipsburg quadrangle. Weed and others, ${ }^{5}$ however, included these beds in the Teton formation of the Yellowstone Park region, which comprises beds ranging in age from late Pennsylvanian to Triassic, and forming three dissimilar lithologic units. The grouping is somewhat similar to that of the Embar formation of Wyoming, which includes Pennsylvanian and Permian limestone and Triassic shale.

The plane of contact between the Phosphoria and Quadrant proper is not easily drawn in all places, for the reason that there is no marked change in the lithology of the beds. The line of division is commonly marked by a few inches of conglomerate and a nonpersistent bed of phosphate rock, apparently of clastic origin. It is suspected that these beds denote an unconformity. The overlying rock is dark-gray cherty quartzite with scattered phosphorite granules, differing chiefly in color from the purer quartzitic sandstone below, which is pinkish gray, cross-bedded, and intercalated with argillaceous creamy limestone.

The Phosphoria is notably siliceous, being either cherty or quartzitic almost throughout. In Yellowstone Park and to the west along and near the Idaho State line the irregular layer of phosphate rock at the base is made up of fragments of phosphatized shells of the brachiopod

\footnotetext{
1 Richards, R. W., unpublished manuscript.

2 Stone, R. W., and Bonine, C. A.,The Elliston phosphate field, Mont. U. S. Geol. Survey Bull. 580, p. 375, 1914.

${ }^{3}$ Peale, A. C., U. S. Geol. Survey Geol. Atlas, Three Forks folio (No. 24), 1896.

${ }^{4}$ Calkins, F. C., and Emmons, W. H., U. S. Geol. Survey Geol. Atlas, Philipsburg folio (No. 196), 1915.

5 Hague, Arnold, Iddings, J. P., Weed, W. H., Walcott, C. D., Girty, G. H., Stanton, T. W., and Knowlton, F. H., Geology of the Yellowstone National Park: U. S. Geol. Survey Mon. 32, pt. 2, 1899.
}

Lingulidiscina utahensis, together with fossil bones. In some places the phosphatio material appears as a resinous brown substance, forming a cement for the quartz sandstone. At 30 to 60 feet above the base of the Phosphoria occur other phosphatic beds consisting of one or more layers of gray to black oolitic phosphorite and perhaps a few feet of dark shale overlain by chert either in thin wavy layers or as nodular masses mixed in an irregular manner with brownish quartzitic sandstone. At irregular intervals in the sandstone there are peculiar distorted cylindrical columns of lighter-colored sandstone 1 to 4 inches in diameter, perpendicular, or nearly so, to the bedding planes. Both the shale and the phosphate beds are lacking a short distance northeast of a line drawn from Helena to the northwest corner of Yellowstone Park. The uppermost beds of the Phosphoria contain poorly preserved brachiopod shells and fish bones, probably of Permian age.

\section{TETON FORMATION.}

The Teton formation, as defined by Weed for Yellowstone Park, included the rocks now named Phosphoria formation, and the overlying Triassio brown shaly limestone and red sandy shale. The brown limestone is unmistakably related to the Dinwoody formation of western Wyoming. This relation was suspected by Blackwelder, ${ }^{6}$ who states that the lower part of the Teton formation is probably equivalent to the Embar of Wyoming. The overlying red shale is in part equivalent to the Chugwater formation of Wyoming and probably to the Thaynes limestone of Idaho. The part of the Teton beds overlying the Phosphoria is approximately 800 feet thick along the Idaho State line west of Yellowstone Park, but-as shown by figure 14 this part was beveled by the Jurassic erosion and completely removed north of latitude $45^{\circ} 30^{\prime}$, both west and east of Yellowstone Park.

Fossils of Triassic age are plentiful in the shaly brown limestone. No fossils were found in the red shales, but above them is locally a bed of richly fossiliferous limestone which at one point along the Idaho State line south of Red Rock Lakes was found to contain a pleurotomarioid gastropod, possibly identical

${ }^{6}$ Blackwelder, Eliot, A reconnaissance of the phosphate deposits in western Wyoming: U. S. Geol. Survey Bull. 470, p. 455, 1911. 
with or closely resembling one that occurs in pods. These beds, which are wholly nonthe Thaynes limestone in southeastern Idaho. marine, lie between the marine Jurassic and The paleontologic and lithologic evidence at marine Upper Cretaceous beds. On the basis hand does not warrant positive statements as to the relations of the upper part of the Teton to the Idaho or Wyoming sections. Exclusion from the Teton of the basal portion, equivalent to the Phosphoria formation, leaves the higher shaly brown limestone and red beds of Triassic age to which the name Teton could be applied, but this seems inadvisable for several reasons, one of which is that the name has not been used for areas outside of Yellowstone Park. It is therefore believed that the use of the name Teton will be discontinued when enough additional field work shall have been done both in Montana and southeastern Idaho to permit the proper application of formation names now in use in Idaho and Wyoming.

\section{ELLIS FORMATION.}

In late Jurassic time, subsequent to a long erosion interval during which there was more or less tilting of the strata, a subsidence brought in from the northwest an arm of the sea in which were deposited the sediments of the Ellis formation. The rocks consist of fossiliferous greenish shale and limestone and a variable amount of rust-brown weathering sandstone and conglomerate. At Elkhorn mining camp, near Helena, and for 70 miles to the south, the Ellis beds rest on more or less disturbed strata of the Phosphoria formation, but farther south the Ellis and Phosphoria are separated by Triassic shaly beds that thicken southward and constitute a portion of the Teton formation. The Ellis beds are about 200 feet thick in Yellowstone Park but thicken northward and northwestward to about 400 feet in the Livingston and Philipsburg regions. It is suspected that the Ellis represents only the basal portion of the several thousand feet of the marine Jurassic beds in southeastern Idaho but corresponds closely with the Sundance formation of Wyoming.

\section{KOOTENAI FORMATION.}

Overlying the Ellis formation is a motley aggregation of beds consisting in great part of red and green shale with conglomeratic sandstone and quartzite, and including near the top a limestone member crowded with gastro-

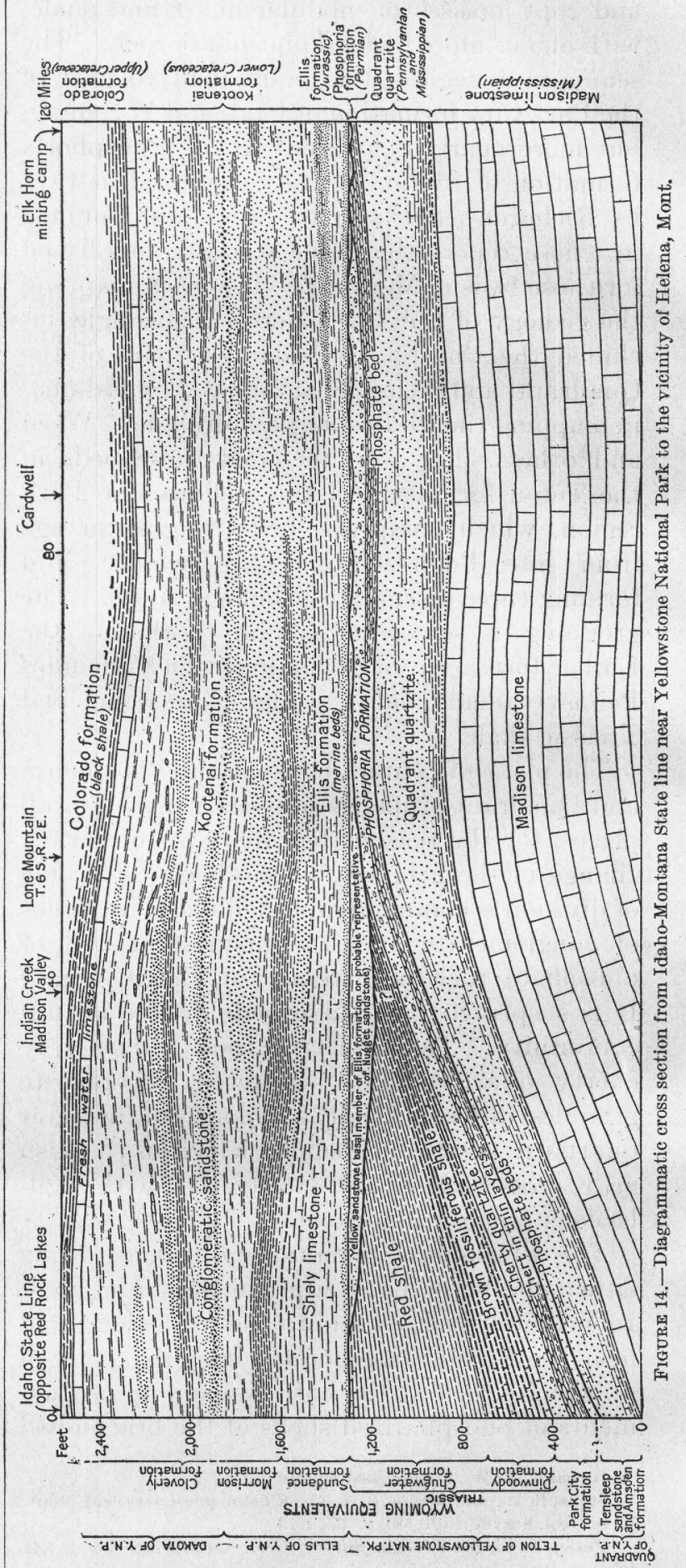

of lithology they are correlated with the Kootenai formation of the Philipsburg quadrangle, which is Lower Cretaceous. They 
Near Cardwell,

Mont.
Indian Creek
T.8S.,R.2E.

Montana
principal meridi

FEET

2,000

1,900

1,800

1,700

1,600

1,500

1,400
1,300

1,20

1,100

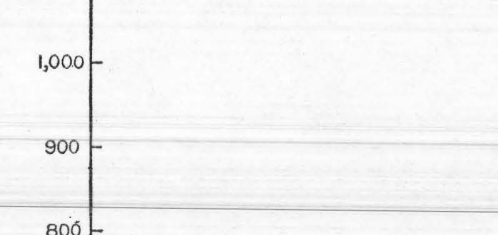

800

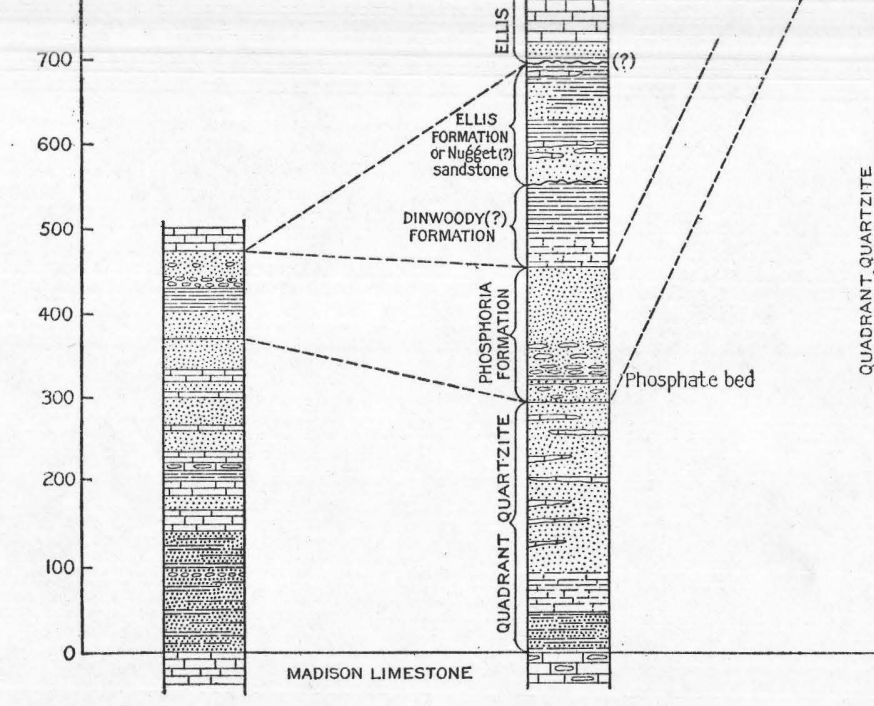

700
.600

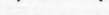

Idaho-Montana

State line
near Red Rock Lakes

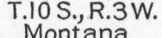

principal meridian

Quadrant Mountain Yellowstone
National Park

Dinwoody Lake,Wyo.

W. $4 \mathrm{~N}, \mathrm{R} .5 \mathrm{~W}$.

FEET

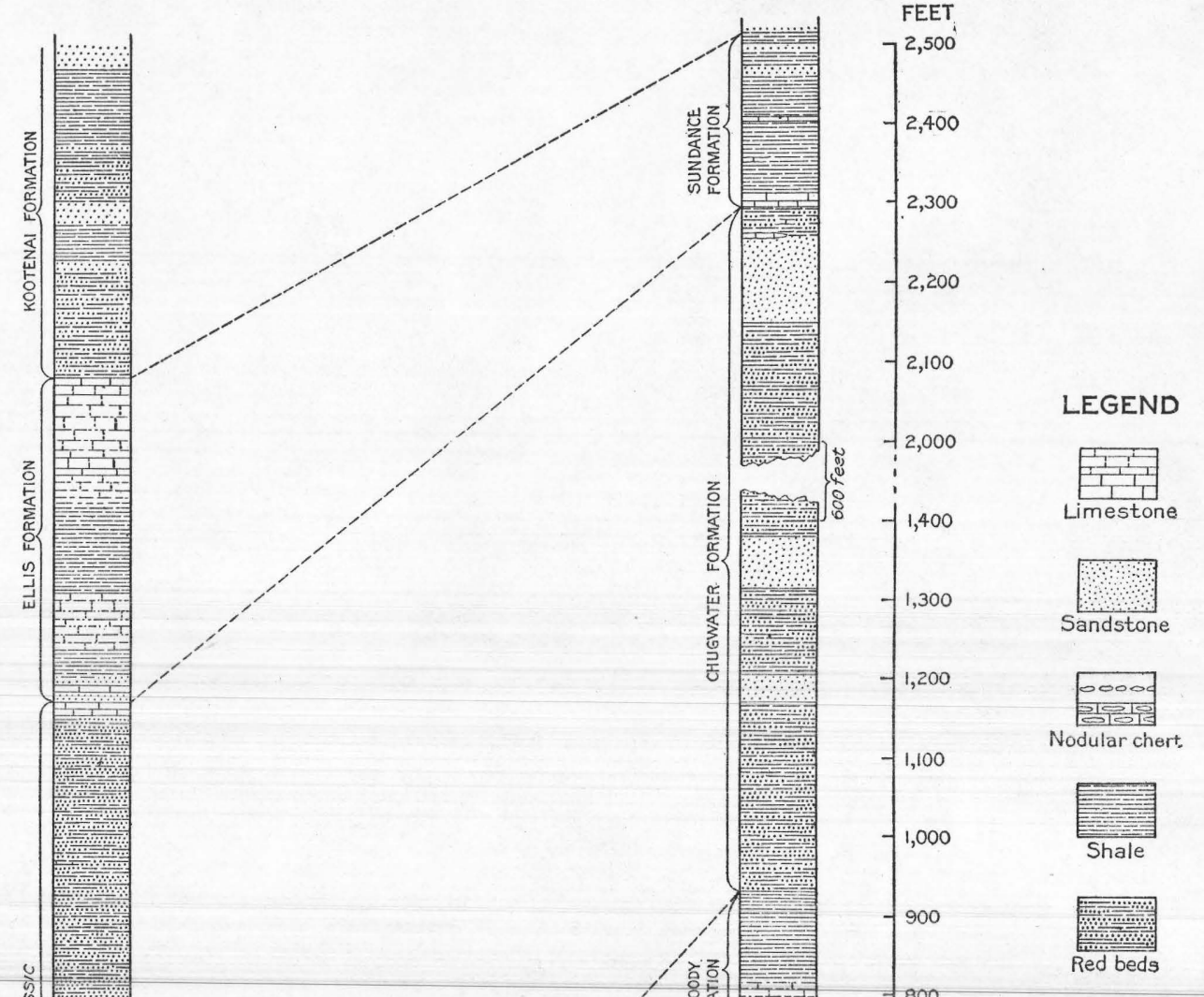



may possibly include the equivalent of the Morrison formation. The thickness of the Kootenai ranges from 1,000 to 1,500 feet.

The most conspicuous beds of the Kootenai are the gray gastropod limestone and a bed of conglomeratic sandstone in about the middle of the formation, the pebbles of which are dark chert. Both the beds are reported at many places in western Montana, in Yellowstone Park, and in the adjacent country in Wyoming. They form hogbacks projecting above the poorly exposed shaly, red beds of the Kootenai and the dark shale of the overlying Colorado formation.

STRATIGRAPHIC DETAILS IN THE MONTANA AND YELLOWSTONE PARK AREA.

$$
\text { [See P1. X.] }
$$

\section{JEFFERSON RIVER CANYON NEAR CARDWELL}

A few miles east of Cardwell, which is on Jefferson River near the mouth of Boulder River, the broad valley narrows to a sharp canyon just wide enough for the tracks of the two railroad lines between the river and steep cliffs. On the south side of the valley (locality 1, Pl. IX) are complete exposures of the Quadrant and Phosphoria formations, dipping steeply northwestward. Several faults introduce some doubt as to the total thickness, but the sequence of the beds is clear. A condensed section of the beds measured here follows:

$$
\text { Section near Cardwell, Mont. }
$$

\section{Ellis formation}

Limestone, sandy, impure, cross - bedded; weathers to rust-brown color; lower beds contain fossils.

Phosphoria formation:

Quartzite, dark gray, containing a few quartz pebbles and bands of chert and a layer of travel-rounded chert pebbles at top..........

Chert in thin shaly layers...................

Phosphatic beds consisting of phosphate rock, limestone, sandstone, shale, and chert, mostly in thin beds.

Sandstone, dark gray, slightly dolomitic and cross-bedded, containing peculiar ropy masses and markings. ................... Quadrant quartzite:

Quartzite, alternating with dolomitic limestone and thin chert layers; poorly preserved fossils in lower part.........................

Limestone, dolomitic and arenaceous, containing alternating thin layers of chocolate-brown shale and nodular chert; fossils fairly abundant in limestone but poorly preserved...................
Shale, brick-red

Conglomerate, with matrix of limestone containing rounded pebbles of chert, limestone, and sandstone...............................

Shale, brick-red, alternating with shaly sandstone, with conglomerate made up of pebbles of Madison limestone resting on uneven surface of Madison limestone...............................

\section{INDIAN CREEK, MADISON VALLEY.}

Indian Creek joins Madison River from the east a few miles south of Cameron. Its branches drain a rugged area containing numerous alpine peaks in the heart of the Madison Range. From a densely timbered basin in the Mesozoic rocks the upper waters of the stream unite and flow westward through a sharp canyon (Pl. XI, $A$ ) in pre-Cambrian rocks bordered on the east by Paleozoic rocks that dip steeply northeastward. In secs. 20 and $21, \mathrm{~T}$. 8 S., R. 2 E., on the north canyon wall (locality 2, Pl. IX), there are complete exposures of strata from the Madison limestone to the top of the Kootenai, stratigraphically nearly 2,000 feet higher. A fault of large displacement cuts the lower Paleozoic strata at this point but does not affect the sequence of the higher strata. A condensed section of beds measured here is given below.

\section{Section on Indian Creek, Mont.}

Kootenai formation: Ft. in

Limestone, gray, smooth textured, crowded with gastropods in basal portion...........

Shale, ferruginous, with a few sandy layers and a layer of ocher-yellow blocky limestones, lavender-colored on fresh fracture.. 400

Sandstone, quartzitic.................. 38

Shale, variegated red and brown......... 64

Sandstone, coarse, with irregular conglomeratic layer in the midst, the pebbles mostly dark chert....................... 32

Shale and clay with carbonaceous layers...... 49

Sandstone, coarse, arkosic, with undulating base........................... 158

Shale, yellowish gray, with sandy layers...... 59

Shale, reddish, with sandy layers........... 109

Ellis formation:

Shale, bluish gray to green, with layers of impure limestone..................... 98

Sandstone, green, friable................ 14

Limestone, granular, gray, rich in fossils.... $\quad 32$

Shale, greenish, weathering yellow.......... 18

Limestone, gray, sparingly fossiliferous..... 51

Limestone, gray, shaly, richly fossiliferous... 88

Shale, calcareous, gray, fossiliferous........ 28

91 Unconformity (?). 
Ellis formation-Continued.

Basal member of Ellis or possibly equivalent of Nugget sandstone of western Wyoming:

Shale, ocherous, sandy, gypseous in upper 89 part....................... 89

Shale, calcareous, sandy............. 12

Limestone, impure, sandy ............ 13

Sandstone, cross-bedded, yellowish, friable.

Unconformity.

Triassic marine beds:

Shale, sandy, grading downward into thinbedded limestone that weathers sepiabrown, closely resembling the Dinwoody of Wyoming, containing Lingula n. sp. and other fossils......................... 102

Phosphoria formation:

Sandstone, dark gray, containing irregular chert layers and columnar rods of lightercolored sandstone................... 65

Chert in thin dark wavy layers............ 33

Phosphatic beds:

Phosphate rock, gray, coarsely oolitic....

Limestone, dark gray..................

Shale.

Phosphate rock, black, oolitic, friable, with 2 inches of shale near middle; 59.52 per cent tricalcium phosphate..

Shale, carbonaceous..................

Phosphate rock, impure, containing fish bones....................................

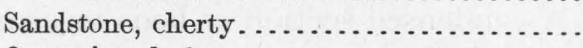

Quartzite, dark gray..................

Shale.

Limestone, sandy, containing phosphatized fossil fragments and travel-rounded chert pebbles.

Quadrant quartzite:

Sandstone, quartzitic, gray, cross-bedded, not measured.

There is some question as to the lower limit of the Ellis formation in the preceding section. It seems clear that the position of the great unconformity is at the base of the yellow sandstone that rests on the Triassic marine beds, but the overlying shaly gypsiferous beds apparently represent continental sedimentation in Jurassic time prior to the encroachment of the Ellis Sea and if so would not appropriately be included in the Ellis. Possibly these gypsiferous beds and the yellow sandstone represent the Nugget sandstone of western Wyoming, as suggested in the diagram (fig. 14).

\section{SNOWCREST MOUNTAINS.}

The Snowcrest Mountains are west of Ruby River, about 20 miles a little west of south from Virginia City. The highest peaks, more than 10,000 feet in elevation, are capped by

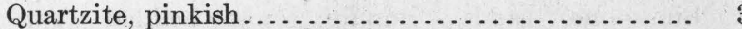

Limestone, dark gray, shaly to massive layers, with scattered brown to black chert nodules; fossils extremely abundant, especially in shaly limestone

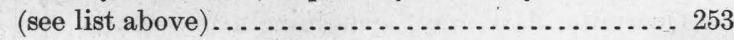

Rocks poorly exposed ....................... 50

Sandstone, conglomeratic at base, possibly basal member of Quadrant formation; approximate thickness. 20

Rocks not exposed........................ 25

Limestone of fissile shaly structure, rich in fossils. This is apparently a part of the Madison but represents a phase not found elsewhere to the east or southeast.

\section{IDAHO-MONTANA STATE LINE OPPOSITE RED} ROCK LAKES.

On the State line between Idaho and Montana, in the Centennial Range south of the Red Rock Lakes (Pl. XII), about 35 miles southeast of the locality in the Snowcrest Mountains above described, the Quadrant formation proper is greatly reduced in thickness, being 


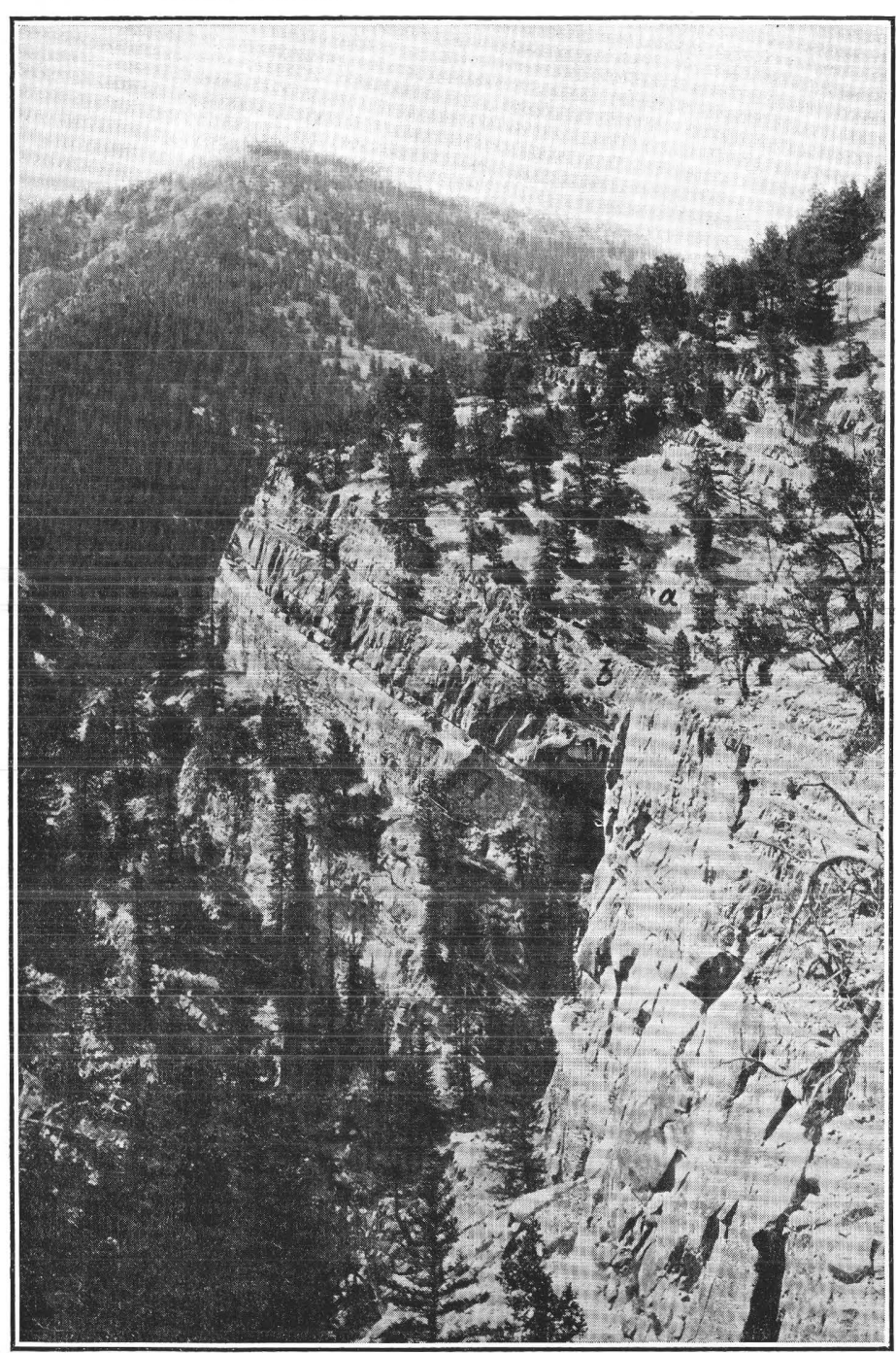

A. CANYON OF INDIAN CREEK, MADISON RANGE, MONT.

Showing cliffs of quartzite of the Phosphoria formation $(b)$ overlain by shaly Mesozoic

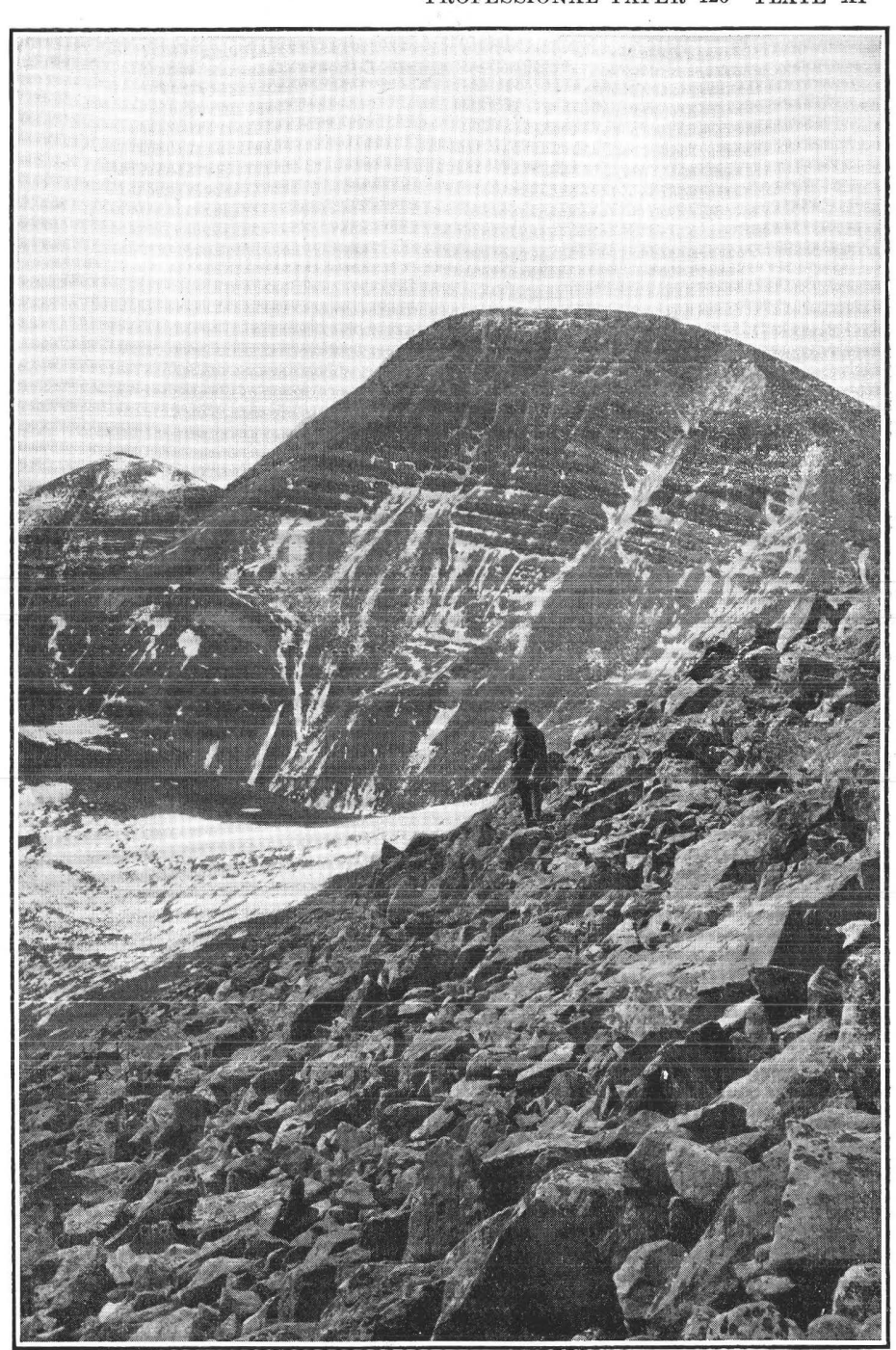

B. PRINCIPAL PEAK IN SNOWCREST RANGE, MONT. Consisting of Madison limestone (lowest exposures in view), overlain by shaly
limestone of the Quadrant quartzite capped by quartzitic beds which form the 


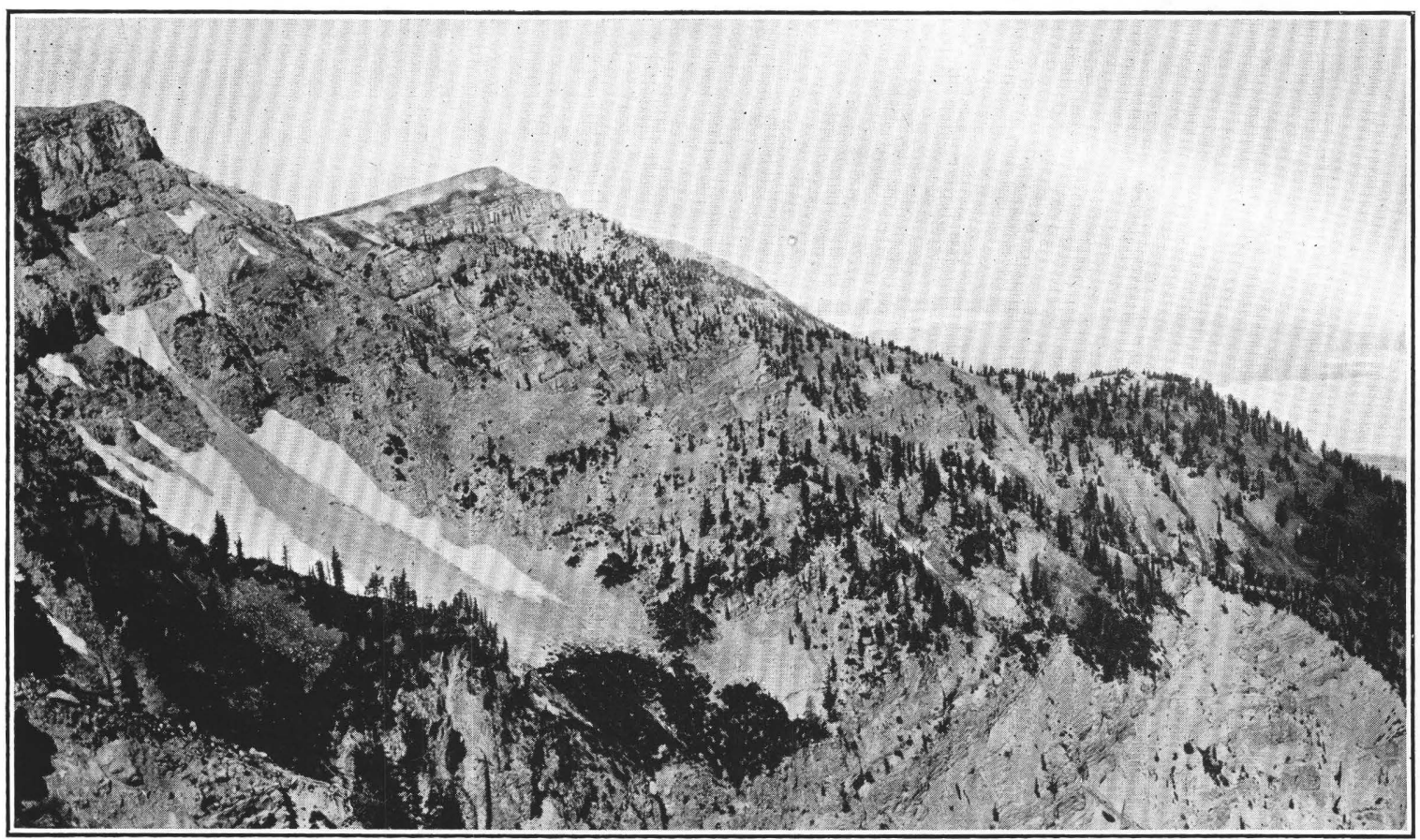

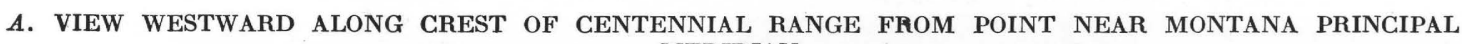
MERIDIAN.

Bed Rock Lakes in distance. The rocks are Phosphoria formation, Quadrant quartzite, and Madison limestone.

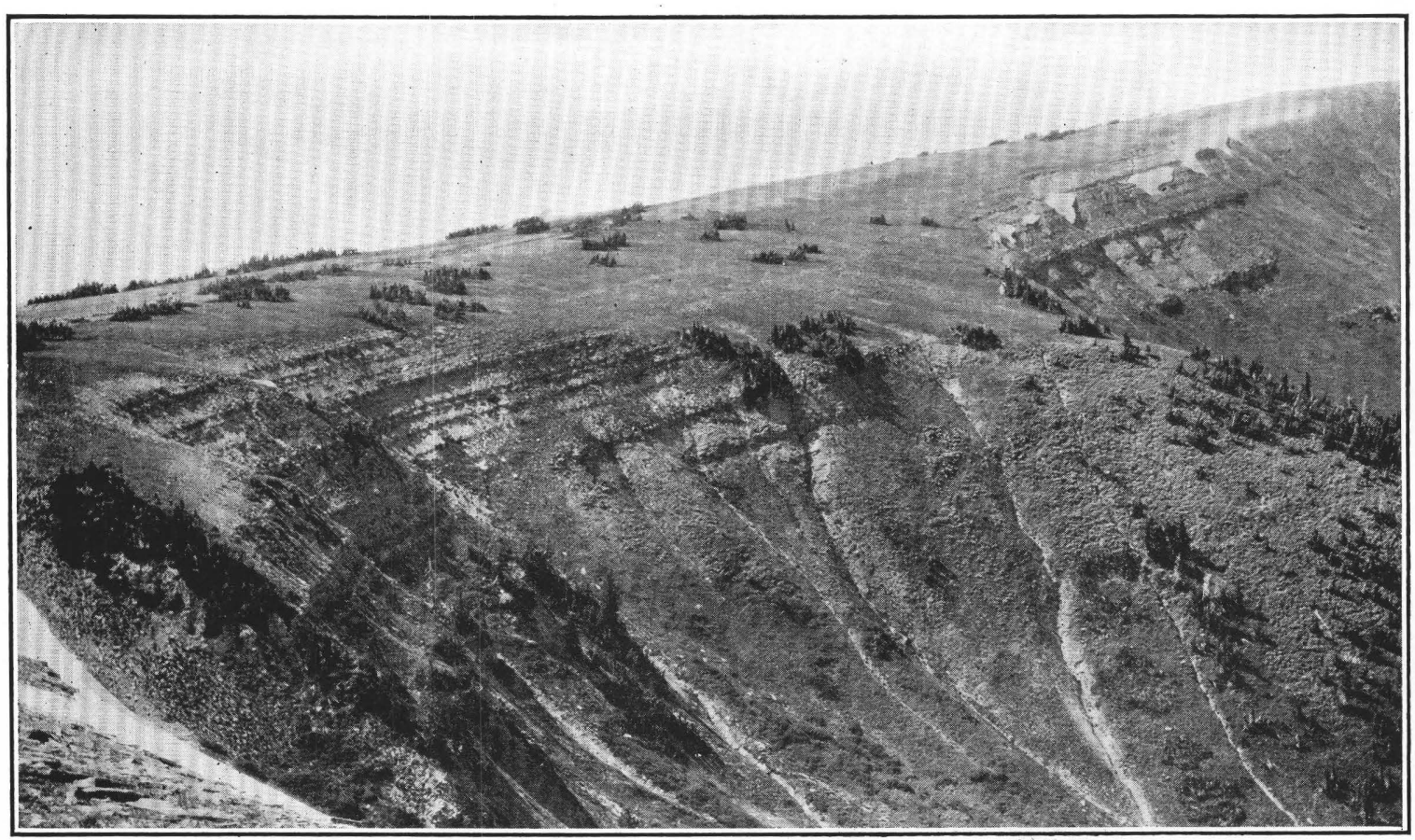

B. SHALY CALCAREOUS BEDS ALONG CREST OF CENTENNIAL RANGE, EQUIVALENT TO DINWOODY FORMATION OF WYOMING. 
probably no more than 200 feet thick, as compared with 900 feet in the Snowcrest locality. The upper sandy beds and underlying fossiliferous limestone are present, however, and a fossil collection shows close relation with the fauna of the thick shaly limestone in the Snowcrest section. The red shale usually observed at the base of the Quadrant is absent, and there is only a few feet of ocherous sandy beds resting on the massive white saccharoidal Madison limestone.

The Phosphoria formation at this point resembles in lithology the beds exposed on Indian Creek but contains in addition a valuable bed of phosphate rock at the base, nearly 4 feet thick and carrying 70 per cent of tricalcium phosphate. This bed, which is evidently of clastic origin, consists chiefly of fragments of phosphatized shells of the fossil Lingulidiscina. At the base there is a few inches of quartz or chert conglomerate marking the lower limit of the Phosphoria formation.

\section{QUADRANT MOUNTAIN, YELLOWSTONE PARK.}

Quadrant Mountain, a prominent topographic feature in the northwestern part of Yellowstone National Park, presents bold exposures of the quartzitic beds which have been named Quadrant quartzite, as explained on pages 111-112. Below is given part of a section measured by Weed ${ }^{1}$ at the southeast end of the mountain (locality 5, Pl. IX). The portion of the Teton assigned to the Phosphoria under the new classification is indicated.

Section on Quadrant Mountain, Yellowstone National Park.

Teton:

[Measured by W. H. Weed.]

Sandstone, red and orange-colored, coarsely granular; weathers in blocks.............. 15

Calcareous shale, dark slate-colored, fossiliferous.

Limestone, bright yellow, fissile, with platy débris, grading into yellow and red spotted calcareous sandstones below................. 40

Shales, light greenish drab, changing to red and grading into overlying beds............... 75

Conglomerate of red and gray quartz pebbles in limestone matrix....................... 10

Cherty sandstone, the lower part without chert, is brown; slightly calcareous at base, becoming more so above [Phosphoria formation]........ 100

Quadrant:

Limestone, dense, white, weathering same color.. 10 Sandstone and limestone in alternating bands.... 15 Limestone, light gray and dense and pure...... 12

${ }^{1}$ U. 8. Geol. Survey Mon. 32, pt. 2, p. 34, 1899.
Quadrant-Continued. Feet.

Quartzite, pure white, thin bedded; forms a persistent band along face of mountain.......... 6

Quartzite, more thickly bedded, white......... 65

Limestone, very light gray, somewhat dense, containing very small fragments of light-colored chert............................. 10

Quartzite, white, calcareous, with intercalated bands of limestone carrying quartzite fragments 30

Limestone, light gray, with angular fragments of sandstone...........................

Quartzite, white, weathering pink and rust color but appearing black when seen from a distance, owing to the growth of lichens upon it. . . . . 130

Limestone, light gray, dense............... 2

Sandstone, well banded, white, saccharoidal..... 6

Sandstone, very calcareous, saccharoidal, white and rust color. ....................... 10

Talus slope of sandstone blocks; also of cherty limestone............................. 100

Additional sections measured at several places on Quadrant Mountain during the present investigation are given below. The Phosphoria exposures were found at the south end of The Pocket, a peculiar natural amphitheater cut into the plateau surface of the mountain top. Complete exposures of the Quadrant quartzite were found about 2 miles to the southwest, on the north face of Bannock Peak. (See Pl. XIII, A.)

Detailed section of Quadrant and higher formations on QuadTriassic beds: rant Mountain.

Limestone, gray, thin bedded; weathers sepia-brown; grades up into shaly, sandy yellowish beds overlain by red shale;

Lingula n. sp. is plentiful in the limestone $60+$

Phosphoria formation:

Sandstone, dark gray, with scattered chert nodules............................ $15 \pm$

Chert, in ropy masses and wavy layers, with irregular sandy layers in upper part.......

Sandstone, dark gray, with cauda-galli markings on bedding and scattered siliceous nodules and ropy masses; fishbones plentiful.............................

Phosphatic rock, gray, with green specks....

Sandstone, dark gray, with markings; chert and fishbones similar to those in 9-foot sandstone above.......................

Quartzite, dark gray....................

Phosphate rock, sandy, resinous; has brown appearance on fresh fracture; contains fragments of Lingulidiscina...............

Quartzite, gray, phosphatic in upper part... Quadrant quartzite:

Limestone, dolomitic, white, finely crystalline......................... 7

Sandstone, gray, cross-bedded........... 16

Limestone, dolomitic, white, finely crystalline........................... 23
Ft. in. 
Quadrant quartzite-Continued.

Sandstone, quartzitic, alternating with sandy dolomitic beds; poorly preserved fossils plentiful near base.................. 350

Shale, red, sandy, slightly calcareous........ 11

Sandstone, conglomeratic, yellow and red, resting on Madison limestone............ 18

The beds above the Quadrant quartzite in this section constitute the Teton formation.

\section{FORMATIONS IN WEST-CENTRAL WYOMING.}

The sequence of late Paleozoic and early Mesozoic formations in west-central Wyoming is represented in the following table. Their probable equivalence with the section to the northwest in Yellowstone Park and Montana is indicated in Plate $\mathrm{X}$.

Late Paleozoic and early Mesozoic formations in westcentral Wyoming.

Sundance formation (Jurassic), limestone, green shale, and sandstone...................200- 300

Chugwater formation (Triassic), largely red sandy shale, with sandstone and more or less gypsum......................... 800-1, 400

Dinwoody formation (Triassic), shaly brownish fossiliferous limestone.................. 50- 200

Park City formation (Permian and Pennsylvanian), fossiliferous limestone and shales... 150- 225

Tensleep sandstone (Pennsylvanian)......... 200- 500

Amsden formation (Pennsylvanian and late

Mississippian), sandstone, limestone, and

shale.............................200-300

It has been shown by the writer ${ }^{1}$ that although the Chugwater red beds are in large part Triassic, the lower portion in the Big Horn Mountains and elsewhere in central Wyoming is of earlier Triassic, Permian, and Pennsylvanian age and was deposited contemporaneously with the marine Triassic (Dinwoody) and Permian and Pennsylvanian (Park City) beds to the west.

\section{AMSDEN FORMATION AND TENSLEEP SANDSTONE.}

The Amsden formation, which rests on the Madison limestone, is somewhat similar in lithology to the lower portion of the Quadrant quartzite of Montana, with which it is correlated, but at no place has it been found to contain richly fossiliferous beds, such as have been discovered in Montana. In the western part of the Wind River Mountains the Amsden consists of massive white sandstone at the

${ }^{1}$ Condit, D. D., Relations of the Embar and Chugwater formations in central Wyoming: U. S. Geol. Survey Prof. Paper 98, pp. 263-270, 1916. base, overlain by interbedded gray to yellowish shale, sandstone, and thin beds of limestone. Some of the shale beds are deep red.

The Tensleep consists almost entirely of sandstone, with a few interbedded dolomitic layers that locally contain marine fossils. The beds correspond so closely in position, thickness, and lithology with the upper portion of the Quadrant quartzite that there is no question as to their correlation. It is suggested also that the Tensleep may be in part equivalent to the Weber quartzite of southeastern Idaho and Utah.

\section{PARK CITY FORMATION.}

Above the Tensleep sandstone in the Wind River Mountains is a sequence of prevailingly calcareous beds correlated by Blackwelder ${ }^{2}$ with the Park City formation of Utah on the basis of paleontologic and lithologic evidence. The Park City beds, together with overlying calcareous brownish shaly beds of Triassic age, constitute the Embar formation of Darton, ${ }^{3}$ who applied this name to strata believed to be of "Permo-Carboniferous" age, lying between the Tensleep sandstone and Chugwater red beds at a locality in the Owl Creek Mountains. This grouping into one formation of beds of Pennsylvanian, Permian, and Triassic age and of widely different lithology is comparable to the grouping of the beds in the Teton formation of Yellowstone Park, and the only reason for retaining Embar as a formation name is its convenience as a term for use in areas where the Dinwoody and Park City can not be differentiated.

The portion of the Embar formation equivalent to the Park City beds in the Wind River and Owl Creek mountains (see Pl. XIII, B) consists largely of limestone with calcareous shale and nodular chert. The general sequence is as follows:

Generalized section of Park City formation in Wind River and Owl Creek mountains, Wyo.

Siliceous greenish limestone grading up into gray resistant limestone, with abundant fossils including Derbya, Pseudomonotis, Leioclema, and Spiriferina pulchra.

Nodular greenish phosphatic chert interbedded with many shale laminae.

2 Blackwelder, Eliot, Stratigraphy of the Wind River Mountains, Wyo.: U. S. Geol. Survey Bull. - (in preparation).

3 Darton, N. H., Geology of the Bighorn Mountains: U. S. Geol. Survey Prof. Paper 51, p. 35, 1906. 


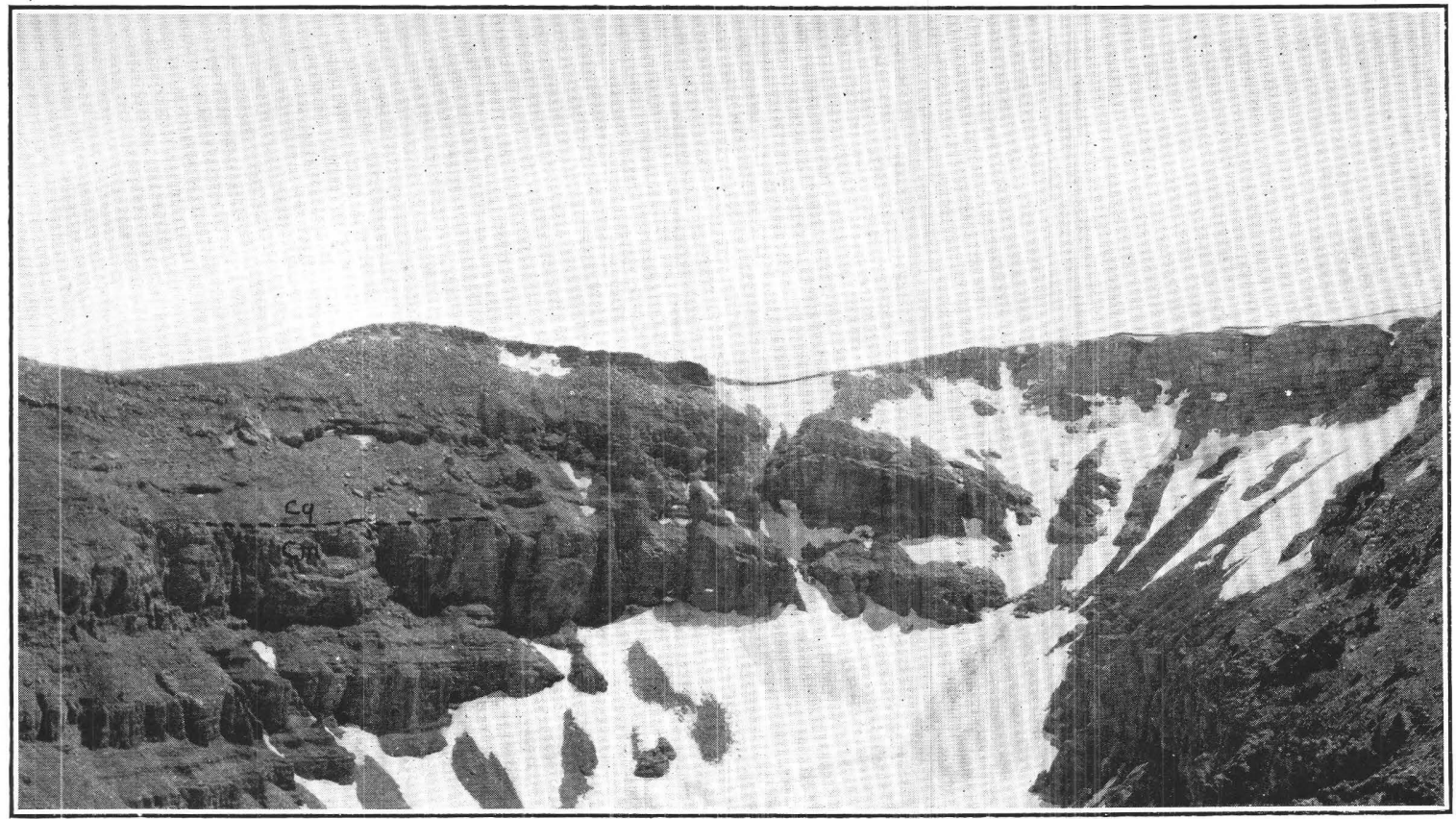

A. NORTH FACE OF BANNOCK PEAK, YELLOWSTONE NATIONAL PARK.

Showing Madison limestone $(\mathrm{Cm})$ and Quadrant quartzite $(\mathrm{Cq})$ at head of cirque valley.

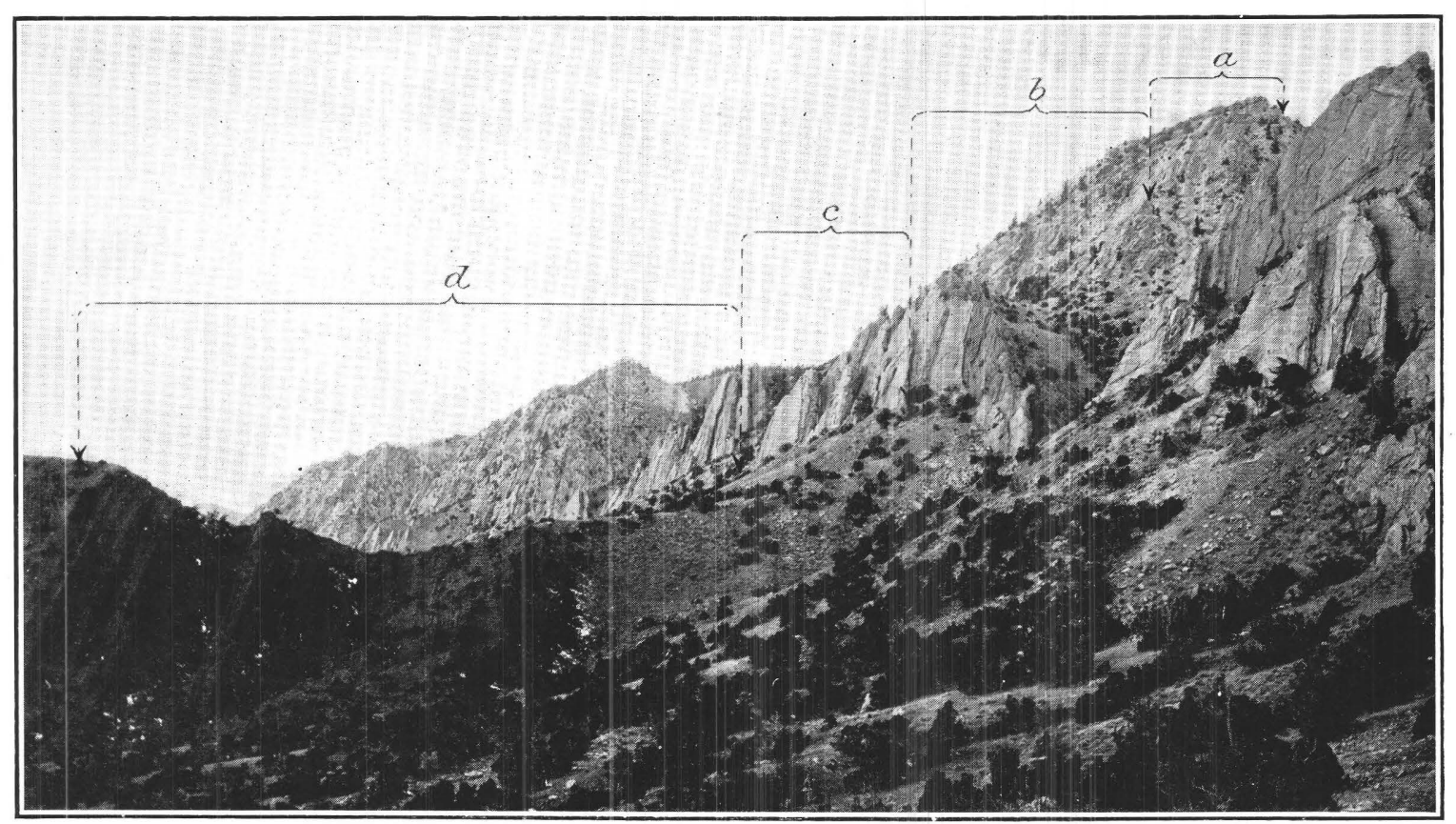

B. UPTURNED BEDS ON SOUTH SLOPE OF OWL CREEK MOUNTAINS, WYO., NEAR SHOTGUN CREEK, T. 7 N., R. 1 E.

$a$, Tensleep sandstone, forming highest hills; $b$, Park City formation, with resistant upper limestone member; $c$, shale of Dinwoody formation, mostly covered by talus; $d$, shaly red beds of Chugwater formation. 

Phosphatic shale of sepia-brown color, with one or more layers of oolitic phosphate rock and phosphatic limestone at the base.

Limestone with geodes, chert masses, and many fossils, among which are Productus nevadensis, Leioclema, Spiriferina pulchra, and Productus subhorridus.

Argillaceous shaly limestone and sandy calcareous shale of yellowish color.

Dolomitic gray fossiliferous limestone, resting with slight unconformity on the Tensleep sandstone.

Paleontologic data recently presented by Branson ${ }^{1}$ support the belief of Girty that the lower portion of the Park City beds is of Pennsylvanian age. Branson's conclusions are the result of study of both vertebrate and invertebrate fossils.

\section{DINWOODY FORMATION.}

The name Dinwoody formation has been adopted for the upper shaly portion of the Embar on the suggestion of Blackwelder, from Dinwoody Canyon, in the Wind River Mountains, where the formation, about 200 feet thick, consists of pale-green to white clay and shaly limestone that weather brown and contain obscure pelecypod shells. The Park City and Dinwoody beds found at this locality are described by Blackwelder in an unpublished bulletin on the stratigraphy of the Wind River Mountains. The consensus of opinion of several observers is that the Dinwoody beds are to be correlated with the Woodside shale (Lower Triassic) of southeastern Idaho. The beds are lithologically identical with strata in the middle portion of the series of beds in Yellowstone Park designated the Teton formation by Weed.

A complete section of the Embar measured by Blackwelder ${ }^{2}$ at Dinwoody Canyon is given below.

\section{Section in Dinwoody Canyon, Wyo.}

Dinwoody formation:

Pale-green to white clay, with local sandy and calcareous beds, overlain conformably by bright-red sandy shale of the Chugwater formation.......................... 130

Gray shaly limestone, weathering brown..... 28

Alternate calcareous and sandy shale and argillaceous sandstone in thin beds....... 12

Dark argillaceous limestone with shale partings containing many. obscure pelecypod shells......................... 10

1 Branson, E. B., The lower Embar of Wyoming and its fauna: Jour. Geology, vol. 24, pp. 639-664, 1916.

2 Blackwelder, Eliot, A reconnaissance of the phosphate deposits in western Wyoming: U. S. Geol. Survey Bull. 470, pp. 476-477, 1911.
Park City formation: *

Grayish sandy shale, shaly limestone, and shaly sandstone, in alternate beds....... 75

Massive gray crystalline limestone with fossil Bryozoa and brachiopods...............

Nodular greenish-gray clay, greenish limestone, and chert; Spiriferina pulchra, Hustedia meekana, Derbya sp., crinoids, and Bryozoa in abundance..................

Alternating sepia-brown phosphatic and calcareous shale and shaly limestone, with thin beds of chert near the top; abundant Productus nevadensis? near the base.......

Brown shale and soft nodular black and gray phosphate rock interlaminated (30.5 per cent tricalcium phosphate).............

Dark greenish-gray oolitic and argillaceous phosphate rock (41. per: cent phosphate)... Gray to sepia-brown shale, full of oval nodules somewhat more calcareous; abundant Spirifer, Productus, etc. (average 8.5 per cent phosphate).........................

Hard greenish-brown phosphatic limestone, with glauconite grains (23.7 per cent phosphate) .............................

Brown argillaceous limestone and calcareous shale, nodular, as above; abundant Productus nevadensis, P. cora, P. subhorridus, Spiriferina pulchra, Pugnax utah, Bryozoa, etc. ( 8 per cent phosphate).............

Dark-drab or brown fetid limestone in massive beds; upper: layers crowded with Bryozoa........................ 21

Green clay shale with thin beds of chert and platy gray limestone................

Gray speckled phosphatic sandstone.........

Earthy white sandstone...................

Greenish-gray speckled phosphatic sandstone containing Lingulidiscina utahensis, etc. (27.4 per cent tricalcium phosphate)...........................

Light-gray earthy limestone...............

Dark-green shale.......................

Pale-gray smoky dolomite with seams of black chert and pores full of black bitumen..............................

White calcareous sandstone and conglomerate of chert pebbles; lies with obscure unconformity upon the Tensleep sand-

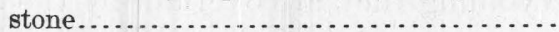

Ft. in.

\section{CHUGWATER, FORMATION.}

The Chugwater red beds, 800 to 1,450 feet thick in west-central Wyoming, present problems in sedimentation that have engaged the attention of a number of workers who are not in agreement as to the origin of these beds. Among their striking features are the uniformity in thickness and texture of individual members over wide areas; the prevalence of ripple marks on horizontal beds through much 
of the formation; the absenee of sun cracks and fossils of land animals except in the upper portion; and the extensive occurrence of gypsum beds near the top. It is not the purpose of this paper to consider in detail the peculiarities of the Chugwater or the different hypotheses concerning its origin. It is evident, however, that mature conclusions can be reached only after a detailed study of the red beds throughout Wyoming and adjacent areas. The question of age alone illustrates this point. In western Wyoming the lowest red beds overlie marine fossil-bearing brown shales of Triassic age that are regarded by several observers as equivalent to the Lower Triassic Woodside shale of Idaho. Furthermore, it is suspected that the lower Chugwater beds of western Wyoming grade laterally into the marine Thaynes limestone of Idaho, which are of Lower Triassic age, or at least that they represent partial-time equivalents of these beds.

A fossil collection made by Darton ${ }^{1}$ in the Big Horn River canyon near Thermopolis, Wyo., is of interest in this connection. The fossils obtained in a limestone 150 feet below the top of the formation were found by G. H. Girty to include Natica lelia, Bakewellia, Pleurophorus, and Aviculipecten, undoubted marine types, constituting a fauna which is referred with considerable confidence to the Triassic. This occurrence is of additional interest as indicating the marine origin of a portion of the Chugwater, as contended by Branson. ${ }^{2}$

In the Big Horn Mountains, in the central part of the State, the lowest red beds of the Chugwater have been shown by the writer ${ }^{3}$ to be of late Pennsylvanian age.

The age of the uppermost beds of the Chugwater formation is uncertain. Wherever present in Wyoming they are overlain by the Sundance formation, which is Upper Jurassic, but it is a question whether the deposition of the gypseous shale, cross-bedded sandstone, and nonmarine limestone characteristic of the upper part of the Chugwater may not have been

\footnotetext{
1 Darton, N. H., Geology of the Bighorn Mountains: U. S. Geol. Survey Prof. Paper 51, p. 40, 1906.

2 Branson, E. B., Origin of the Red Beds of western Wyoming: Geol. Soc. America Bull., vol. 26, pp. 217-230, 1915.

3 Condit, D. D., Relations of the Embar and Chugwater formations in central Wyoming: U. S. Geol. Survey Prof. Paper 98, pp. 263-270, 1916.
}

largely contemporaneous with the early Jurassic base-leveling so plainly recorded in the truncated beds to the north, in Montana.

\section{SUNDANCE FORMATION.}

The Sundance formation of Wyoming is regarded as the equivalent of the Ellis in Montana, with which it agrees fairly well in lithology, thickness, and fossil content. The Sundance consists largely of greenish calcareous to sandy shale, with a resistant dark-gray limestone near the middle. Both the shale and the limestone are richly fossiliferous, and the most characteristic species are Belemnites densus, Gryphaea calceola, and stem segments of the crinoid Pentacrinus asteriscus.

\section{RECORD OF JURASSIC BASE-LEVELING.}

The most striking evidence of prolonged erosion in Jurassic time is furnished by the contact of the late Jurassic marine beds (Ellis) with successively older formations as followed northward across Montana. This feature is graphically shown in figure 14 . The substrata along the Idaho-Montana State line near Yellowstone Park are limestone or red beds of Triassic age, and successively lower formations appear northward to Elkhorn mining camp, about 20 miles south of Helena, where the substrata are beds probably 75 feet below the top of the Phosphoria formation. Fisher ${ }^{4}$ has stated that in places in the Great Falls region, in northern Montana, the Ellis rests on the Madison limestone.

Study of the erosion surface from place to place reveals the presence of peculiar yellowish earthy sandstone, ferruginous gypseous shale, and local limestone beds, all making up a motley aggregate related neither to the overlying Ellis nor to the underlying formations. These heterogeneous materials constitute the sedimentary record of events that preceded or accompanied the advance of the sea from the northwest in late Jurassic time. Their thickness, ranging from a few feet to little more than 100 feet, is direct evidence of the slight relief of the land surface, the inequalities of which were leveled to form the floor upon which the marine Ellis beds were deposited.

4 Fisher, C. A., Geology of the Great Falls coal field, Mont.: U. S. Geol. Survey Bull. 356, p. 27, 1909. 
The thickness of strata removed by Jurassic erosion in northern Montana may have been 2,000 feet, if the Chugwater red beds once extended over that area. The extent to which the Chugwater was eroded in Wyoming is not evident, but it seems probable that in the westcentral part of the State, where the beds are 1,400 feet thick, they remain almost intact, and that the upper portion, including the gypseous beds, may be in part a product of Jurassic sedimentation.

The disposition of the great mass of material stripped from the northern area is a matter of speculation, but in the writer's opinion this erosion may have furnished the sediments of the shale and sandstone series of southeastern Idaho lying between the marine Lower Triassic (Thaynes limestone) and marine Upper Jurassic (Twin Creek limestone). It is probable that in the meanwhile the Wyoming area, a low, nearly level plain, which was intermittently occupied by small bodies of water and in which neither erosion nor deposition of considerable magnitude occurred, furnished the conditions necessary for the formation of extensive but variable gypsum and limestone beds. 